\title{
Expression and Characterization of Six Mutations in the Protoporphyrinogen oxidase gene among Finnish Variegate Porphyria Patients
}

\author{
Mikael von und zu Fraunberg ${ }^{1}$, Raimo Tenhunen, ${ }^{2}$ and Raili Kauppinen ${ }^{1}$ \\ ${ }^{1}$ Department of Medicine, Division of Endocrinology, University Central Hospital of Helsinki, \\ Helsinki, Finland \\ ${ }^{2}$ Department of Clinical Chemistry, University Central Hospital of Helsinki, Helsinki, Finland \\ Accepted January 31, 2001
}

\begin{abstract}
Background: Variegate porphyria (VP) is an inherited disorder of heme biosynthesis that results from a partial deficiency of protoporphyrinogen oxidase (PPOX). Patients with VP may experience acute neurovisceral attacks and cutaneous photosensitivity. To date we have characterized 109 VP patients representing 19 VP families in the Finnish population of 5 million, both biochemically and clinically. Materials and Methods: Mutations were identified by direct sequencing of the patients' genomic DNA. The effect of the mutations was determined by sequencing the reverse transcriptase polymerase chain reaction (RT-PCR) product amplified from total RNA extracted from the patients' lymphoblast cell lines and expressing the mutations in E. coli and COS-1 cells.

Results: Of the six mutations identified in the PPOX gene, three mutations (IVS2-2a $\rightarrow \mathrm{c}, 338 \mathrm{G} \rightarrow \mathrm{C}$, and $470 \mathrm{~A} \rightarrow \mathrm{C}$ )
\end{abstract}

caused splicing defects, one produced a frameshift (78insC) and two mutations (R152C and L401F) caused amino acid substitutions. In RT-PCR, the IVS $2-2 a \rightarrow c$ mutation caused a retention of a 36-bp fragment in the 3' end of intron 2, the $338 \mathrm{G} \rightarrow \mathrm{C}$ mutation caused an exon 4 deletion, and the $470 \mathrm{~A} \rightarrow \mathrm{C}$ mutation caused an exon 5 deletion with retention of a 19-bp fragment of the 3' end of intron 5. In both prokaryotic and eukaryotic expression systems, the PPOX activities of five mutants were decreased to $0-5 \%$ of the normal activity.

Conclusions: This study describes five novel mutations and one earlier described major mutation among Finnish VP patients. All mutations produced detectable transcripts, but resulted in decreased PPOX activity confirming the causality of the mutations and the biochemical defects in these patients.

\section{Introduction}

Variegate porphyria (VP) is an inherited metabolic disease that results from the partial deficiency of protoporphyrinogen oxidase (PPOX), the penultimate enzyme in the heme biosynthetic pathway (1). PPOX catalyzes the six-electron oxidation of protoporphyrinogen IX to the planar, fully conjugated macrocycle protoporphyrin IX in the inner membrane of the mitochondrion and requires oxygen for its activity (2). The PPOX activity is decreased to approximately half in heterozygous VP patients (3). VP is inherited as an autosomal dominant trait displaying incomplete penetrance (1). The biochemical abnormalities found in VP patients include overproduction and increased excretion of porphyrins and porphyrin precursors. Clinical manifestations include acute neurovisceral attacks and

Address correspondence and reprint requests to: Dr. Mikael von und zu Fraunberg, Porphyria Research Center, Department of Medicine, University Central Hospital of Helsinki, P.O. Box 340, 00029 HYKS, Helsinki, Finland. Phone: +358-40-5010208; Fax: +358-9-47174012; E-mail: mikael.fraunberg@hus.fi Mutation R152C partly described earlier in Acta Haematologica (1997) 98(suppl. 1) 1-128 (Abstr.) cutaneous photosensitivity resembling other acute porphyrias (4).

Human PPOX-cDNA has been cloned from a human placental cDNA library (5). The PPOX gene has been mapped to chromosome lq23 using in situ hybridization (6). The gene is $5.5 \mathrm{~kb}$ in size including a 660 -bp promoter region, and the coding region (1.5 $\mathrm{kb}$ ) is spread over 13 exons (7). To date, 81 mutations have been reported in the PPOX gene (8-19).

In Finland, the prevalence of VP has been estimated to be 1.3 in 100,000 (4). To date we have characterized a total of 109 symptomatic VP patients and asymptomatic gene carriers representing $19 \mathrm{VP}$ families, both biochemically and clinically (20). In this study, we describe six mutations in the PPOX gene identified from 17 of the 19 VP families known in Finland. Five of the mutations are novel; the mutation R152C has been previously reported (17).

\section{Materials and Methods Patients and Biochemical Analyses}

A total of 40 symptomatic VP patients or asymptomatic gene carriers, representing 17 Finnish VP families and their 33 relatives, were investigated by DNA analysis $(4,21)$ (Fig. 1). The diagnosis of VP 


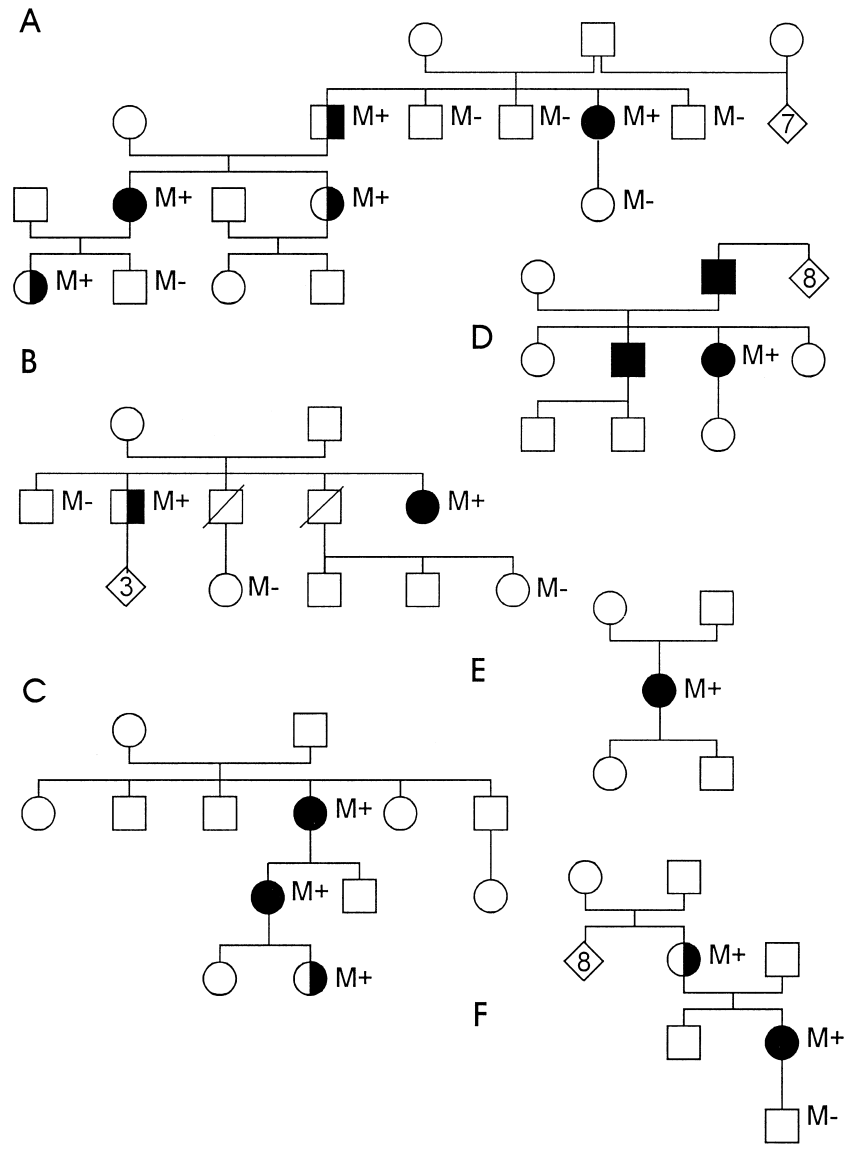

Fig. 1. A-F. Pedigrees of six VP families with novel mutations in the PPOX gene. Closed circle and square $=$ affected female and male with clinically symptomatic disease; Open circle and square $=$ unaffected family member; half-filled circle $=$ asymptomatic individual carrying the affected gene; $\mathrm{M}+=\mathrm{mu}-$ tation positive; $\mathrm{M}-=$ mutation negative.

was based on typical clinical symptoms and elevated fecal protoporphyrin excretion (22), plasma fluorescence emission spectrum, (23) and/or low lymphocyte PPOX activity (3) measured in at least one of the family members.

\section{DNA, RNA Extraction, and cDNA Synthesis}

Leukocyte DNA was released from the venous blood samples with EDTA as an anticoagulant using QIAmp Blood Kit (Qiagen, Hilden, Germany) (24). Total RNA was extracted from Epstein-Barr virustransfected lymphoblastoid cell lines of patients using the guanidium isothiocyanate method $(25,26)$. Complementary DNA was synthesized from 5-10 $\mu \mathrm{g}$ of total RNA using Superscript II Rnase $\mathrm{H}^{-}$Reverse Transcriptase (Gibco BRL Life Technologies, Gaithersburg, MD, USA) and random hexamers or oligo(dT)s.

Polymerase Chain Reaction and Sequencing of Genomic DNA and CDNA

The PPOX gene was amplified in two fragments using GeneAmp XL PCR Kit (Perkin Elmer, Wellesley,
MA, USA) (27). Lower mixture contained dNTPs at $800 \mu \mathrm{M}$ concentrations, $60 \mathrm{pmol}$ of each primer, and $\mathrm{Mg}(\mathrm{OAc})_{2}$ at $1.5 \mathrm{mM}$ concentration in $60 \mu \mathrm{l}$ of the enzyme buffer. Upper mixture, which was separated by a wax layer, contained $100 \mathrm{ng}$ DNA and $4 \mathrm{U}$ rTth DNA-polymerase in $40 \mu \mathrm{l}$ of the enzyme buffer. The primers used for exons 1-7 were: sense (nucleotides -87 to -46$)$ 5'-CAG CAG AGC GCC GGC GGG GTA CGG TCT TAG GAC CTC GAT CTC-3' and antisense $(+785$ to +808$)$ 5'-CTT CCA GCG CCC TTC TGC CTG GAG-3'; and for exons 6-13: sense (+554 to +576) 5'-CCA GTC TCT TCC AAG CTG AGC AA $-3^{\prime}$ and antisense $(+1424$ to +1453$)$ 5'-CAT GAA TGA GAG TTG GGG ATC AGC TGT TAG-3'. The temperature profile for the PCR reactions was $30 \mathrm{sec}$ at $93^{\circ} \mathrm{C}$ for the first denaturation step, followed by $30 \mathrm{sec}$ at $93^{\circ} \mathrm{C}$ and $3-7 \mathrm{~min}$ at $65^{\circ} \mathrm{C}$ for 30 cycles.

In reverse transcriptase polymerase chain reaction (RT-PCR) and polymerase chain reaction (PCR) of genomic DNA samples for restriction analysis, the reaction mixture contained $100 \mathrm{ng}$ DNA, $0.2 \mathrm{mM}$ dNTPs, 20 pmol of primers, and 1 U of DNApolymerase (Dynazyme II; Finnzymes, Espoo, Finland) in $50 \mu \mathrm{l}$ of the enzyme buffer. The temperature profile for the PCR reactions was 2 min at $94^{\circ} \mathrm{C}$ for the first denaturation step, followed by $30 \mathrm{sec}$ at $94^{\circ} \mathrm{C}, 30 \mathrm{sec}$ at $60^{\circ} \mathrm{C}$, and $30 \mathrm{sec}$ at $72^{\circ} \mathrm{C}$ for 30 cycles. The primers used in the RT-PCR were: sense (nucleotides -61 to -17 ) 5'-TTA GGA CCT CGA TCT CCT TCT CCC TCA TTT TCT CTC ATC CCT ACC-3' and antisense $(+1424$ to +1453$)$ 5'-CAT GAA TGA GAG TTG GGG ATC AGC TGT TAG-3' spanning exons 1 to 13 .

The PCR products were purified using the QIAquick PCR Purification Kit (Qiagen). The samples were directly sequenced using the dideoxynucleotide chain termination method (28) with the Amplicycle Sequencing Kit (Perkin Elmer), including $5 \mu \mathrm{Ci} \alpha-{ }^{33} \mathrm{P}$-dATP (Amersham Pharmacia Biotech, Uppsala, Sweden) in each sample. Samples were run in a $6 \%$ polyacrylamide gel (Gene-Page; Amresco, Solon, Ohio, USA) and after drying $1 \mathrm{hr}$ at $+80^{\circ} \mathrm{C}$ autographed using Kodak Biomax MR film (Eastman Kodak, Rochester, NY, USA).

\section{Restriction Site Analysis}

Ten microliters of PCR product and 10-20 U of a restriction enzyme in $30 \mu \mathrm{l}$ of the enzyme buffer were incubated for an hour according to manufacturer's instructions (The New England Biolabs, Beverly, MA, USA). The fragments were run in an ethidium bromide stained $1-4 \%$ agarose gel (Amersham Pharmacia) and visualised using ultraviolet (UV) light.

\section{Prokaryotic and Eukaryotic Expression of PPOX Mutations}

The normal and mutant PPOX cDNAs were expressed in Escherichia coli using the pUCl8-vector (Pharmacia LKB Biotechnology Inc., Picataway, NJ, USA). For the 78insC mutation, the mutagenesis was performed using a Chameleon double-stranded 
site-directed mutagenesis kit (Stratagene Cloning Systems, La Jolla, CA, USA) and a sense primer 5'-CAC CTG AGC CGG GCC CCC TGC CCC CCC TAA GGT GG-3'. For the $454 \mathrm{C} \rightarrow$ T mutation, the mutagenesis was performed similarly using a sense primer 5'-TGT GCA CAG TTT TGC CCA GTG CCG CCT TGG ACC TGA GG-3'. For the IVS2-2 a $\rightarrow$ c mutation, an 864 bp RT-PCR fragment was digested with AvrII and RsrII. The AvrII-RsrII fragment (224 bp) was ligated as a cassette into the corresponding sites of the normal HPPOX-pUCl8 (kindly provided by Prof. S. Taketani, Kansai Medical University, Osaka, Japan) using T4 DNA ligase (The New England Biolabs). For the $338 \mathrm{G} \rightarrow \mathrm{C}$ mutation, an 894 bp RT-PCR fragment was at first digested with BsaI to abolish the wild-type transcript. The mutated fragment was further purified and reamplified and digested with PpuMI for ligation into the corresponding sites of the normal HPPOX-pUC18. For the $470 \mathrm{~A} \rightarrow \mathrm{C}$ mutation, the mutated construct was prepared similarly using PpuMI sites for ligation. The cDNA of each construct was sequenced to confirm its authenticity.

For the eukaryotic expression, the normal and the mutant HPPOX fragments were digested with $E c o R I$ and transferred to the corresponding sites of the modified pCMVl-vector, pCMV5 (29). COS-1 cells were transfected with the mutant constructs or with pCMV5 (negative control) or the HPPOXpCMV5 (positive control) using $100 \mu \mathrm{M}$ chloroquine and $\mathrm{CaCl}_{2}$ precipitation (26). The PPOX activity of COS-1 cells alone was monitored in the presence of chloroquine and $\mathrm{CaCl}_{2}$ precipitation in each series analyzed. The transformed COS cells were incubated for $48 \mathrm{hr}$ before harvesting. Transfection efficiency was controlled by rejecting experiments in which the enzyme activity of the normal allele was less than 2-fold compared to the background activity.

\section{Assay of PPOX Activity}

Crude cell extracts of plasmid-containing cultures were assayed and the enzyme activities obtained were compared to that of the background activity of the PPOX in E. coli or COS-1 cells. Transformed cells were lysed with $300 \mu \mathrm{l}$ of incubation buffer (150 mM Tris-HCl, ImM EDTA, 1\% [v/v] Tween 20) and sonicated ( 3 times $12 \mathrm{sec}$ ), spun down for $10 \mathrm{~min}$ in $+4^{\circ} \mathrm{C}$ and $50 \mu \mathrm{l}$ of the supernatant was used for the PPOX activity assay (3). Protoporphyrinogen was prepared from protoporphyrin IX (Porphyrin Products, Logan, Utah, USA) using sodium amalgam reduction just before use. The protoporphyrinogen solution was diluted with $50 \mathrm{mM}$ GSH-incubation buffer $1: 1(\mathrm{v} / \mathrm{v})$ to avoid autooxidation and $10 \mu \mathrm{l}$ was used as a substrate in the reaction. The assays were carried out at $37^{\circ} \mathrm{C}$ in the dark. At 5 and 25 min, the samples were withdrawn and the reaction was stopped by mixing with $1 \mathrm{ml}$ of $100 \mathrm{mM}$ Tris- $\mathrm{HCl}$, ImM EDTA, $0.1 \%$ Triton-X100 (v/v), pH 8.7, and 2 mM GSH. The background fluorescence was controlled in each series by measuring the buffers only. The formation of protoporphyrin was determined by fluorescence using a Hitachi spectrofluorometer (wavelength of excitation $403 \mathrm{~nm}$, emission $631 \mathrm{~nm}$ ) and the protein concentration was determined by the method of BioRAD Protein Assay (Bio-Rad Laboratories, Richmond, CA, USA).

\section{Results}

Direct sequencing of the PPOX gene was performed for all exons and exon-intron boundary regions after amplification of genomic DNA samples of 17 Finnish VP patients representing their families. In each case the mutation was confirmed by repeating amplification and sequencing in both sense and antisense orientation, and by restriction digestion whenever available. DNA samples of healthy unrelated Finnish controls $(n \geq 40)$ were analyzed to exclude polymorphisms. The consequences of the mutations were studied by amplification and sequencing of the reverse-transcribed total RNA obtained from the patients' Eptsein-Barr virus (EBV)-transformed lymphoblast cell lines. The expression of mutant polypeptides was studied both in prokaryotic and eukaryotic cell lines.

\section{Identified Mutations}

In Family 1 (Fig. 1A), direct sequencing of five patients' amplified genomic DNA demonstrated an insertion of nucleotide $\mathrm{C}$ after nucleotide position 78 in exon 2 (78insC, numbered according to GenBank \#X99450). The insertion causes a frameshift and a premature stop codon occurs 8 codons downstream from the mutation at the $3^{\prime}$ end of exon 2 (Fig. 2A, Table 1). In RT-PCR, the mutation could be identified in the cDNA.

In Family 2 (Fig. 1B), sequencing of two patients' genomic DNA demonstrated a point mutation, IVS2-2 $\mathrm{a} \rightarrow \mathrm{c}$, in the intron 2-exon 3 boundary region (Fig. 2B, Table 1). The mutation was confirmed by restriction cleavage, because it also abolishes a BstNI cleaving site (Fig. 3A). In RT-PCR, the cDNA revealed a splicing defect, where a $35 \mathrm{bp}$ fragment of the $3^{\prime}$-end of intron 2 was transcribed into mRNA (Fig. 2B, Fig. 4A). The $-2 a \rightarrow c$ substitution at the $3^{\prime}$ splice site of intron 2 alters the consensus sequence $(\mathrm{ag} / \mathrm{GT} \rightarrow \mathrm{cg} / \mathrm{GT})$ and a cryptic splice (cag/gc) is activated 35 bp upstream from the authentic splice site. Exons 1 and 2 are transcribed normally, but owing to the uneven number of nucleotides in the inserted fragment, a frameshift occurs in exon 3 resulting in a premature stop codon in exon 3 (Fig. 5). The predicted length of the translated polypeptide is 47 amino acids.

In Family 3 (Fig. 1C), sequencing of three patients' genomic DNA demonstrated a point mutation, 338G $\rightarrow$ C, in exon 4 (Fig. 2C, Table 1). The mutation was also identified from a patient in Family 4 (Fig. ID), which originated from the same area in the 


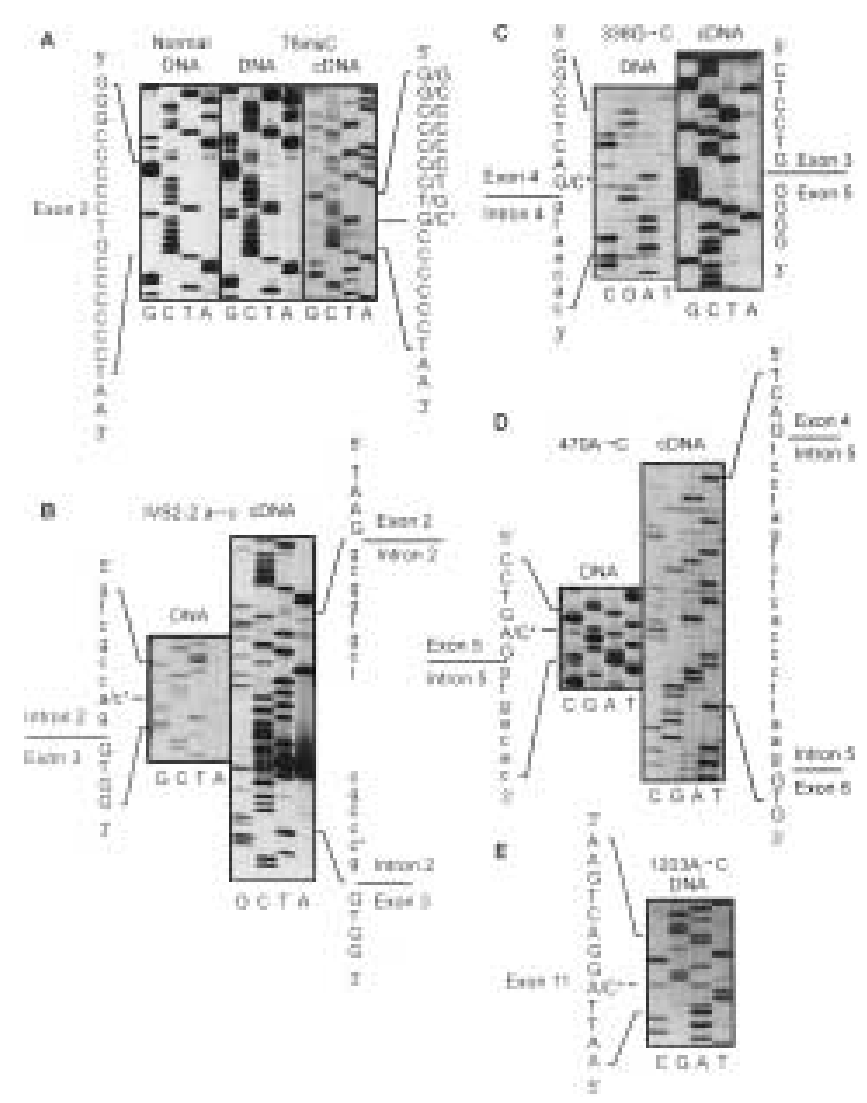

Fig. 2. A-E. Identification of five mutations and their transcriptional consequences by sequencing of the PPOX gene. (A) 78insC. Left normal genomic DNA. Center direct sequencing of a patient's genomic DNA revealing the 78insC mutation; right sequencing of patient's cDNA revealing the mutation. (B) IVS2-2 a $\rightarrow$ c. Left direct sequencing of a patient's genomic DNA; right sequencing of cDNA after subcloning reveals a retention of a 34-bp fragment of the $3^{\prime}$-end of intron 2 in the mutant transcript. (C) $338 \mathrm{G} \rightarrow$ C. Left direct sequencing of a patient's genomic DNA; right sequencing of cDNA reveals deletion of exon 4. (D) $470 \mathrm{~A} \rightarrow \mathrm{C}$. Left direct sequencing of a patient's genomic DNA; right sequencing of cDNA demonstrates a deletion of exon 5 and a retention of a 20-bp fragment of the 3'-end of intron 5 in the mutant transcript. (E) $1203 \mathrm{~A} \rightarrow \mathrm{C}$. Direct sequencing of a patient's genomic DNA. northwestern part of Finland as Family 3. The mutation was confirmed by restriction cleavage because it abolishes a Bsu36I cleaving site (Fig. 3B). In RT-PCR, the cDNA revealed a splicing defect, where exon 4 was deleted (Fig. 2C, Fig. 4B). The RT-PCR revealed a dramatic decrease of the steady state level of the mutant transcript in the patient's lymphocytes compared to that of the normal allele (Fig. 4B). The $-1 \mathrm{G} \rightarrow \mathrm{C}$ substitution at the $5^{\prime}$ splice site of intron 4 alters the consensus sequence (AG/gt $\rightarrow \mathrm{AC} / \mathrm{gt}$ ) and as a result exon 4 is skipped. Exons $1-3$ are transcribed normally, but owing to the uneven number of nucleotides in the deleted fragment, a frameshift occurs in exon 5 resulting in a premature stop codon in exon 5 (Fig. 5). The predicted length of the translated polypeptide is 103 amino acids.

In Family 5 (Fig. 1E), sequencing of a patient's genomic DNA demonstrated a point mutation, $470 \mathrm{~A} \rightarrow \mathrm{C}$, in exon 5 at the exon-intron boundary (Fig. 2D, Table 1). The mutation was confirmed by restriction cleavage because it abolishes a Bsu36I cleaving site (Fig. 3C). In RT-PCR, the cDNA revealed a splicing defect, where exon 5 was deleted, and a 20-bp sequence of the 3'-end of intron 5 was transcribed into mRNA (Fig. 2D, Fig. 4C). The $-2 \mathrm{~A} \rightarrow \mathrm{C}$ substitution at the $5^{\prime}$ splice site of intron 5 alters the consensus sequence (AG/gt $\rightarrow \mathrm{CG} / \mathrm{gt})$. As a result, exon 5 is skipped and a cryptic splice site $(\mathrm{ag} / \mathrm{tc})$ is activated $19 \mathrm{bp}$ upstream from the authentic 3' splice site of intron 5 . The reading frame is not affected and the exons 1-4 and 6-13 are transcribed. The predicted polypeptide contains 112 translated amino acids encoded by exons 1-4 followed by 7 amino acids encoded by the inserted fragment of intron 5 instead of exon 5, and 320 normally translated amino acids encoded by exons 6-13 (Fig. 5).

In Family 6 (Fig. 1F), sequencing of two patients' genomic DNA demonstrated a missense mutation, $1203 \mathrm{~A} \rightarrow \mathrm{C}$, in exon 11 (Fig. 2E, Table 1). The mutation is predicted to result in a substitution of a nonpolar amino acid phenylalanine for nonpolar leucine

Table 1. Characteristics of mutations found from Finnish variegate porphyria patients

\begin{tabular}{|c|c|c|c|c|}
\hline Location & Mutation & Outcome & cDNA & $\begin{array}{l}\text { Mutation-specific } \\
\text { Restriction Enzyme }\end{array}$ \\
\hline Exon 2 & 78insC & Frameshift & + & - \\
\hline IVS 2 & IVS2-2 $\mathrm{a} \rightarrow \mathrm{c}$ & $34 \mathrm{bp}$ retention of intron 2 & + & BstNI \\
\hline Exon 4 & $338 \mathrm{G} \rightarrow \mathrm{C}$ & Deletion of exon 4 & + & Bsu36I \\
\hline Exon 5 & $454 \mathrm{C} \rightarrow \mathrm{T}$ & $\mathrm{R} 152 \mathrm{C}$ & + & HhaI \\
\hline Exon 5 & $470 \mathrm{~A} \rightarrow \mathrm{C}$ & $\begin{array}{l}\text { Deletion of exon } 5 \text { and } 19 \text { bp } \\
\text { retention of intron } 5\end{array}$ & + & Bsu36I \\
\hline Exon 11 & $1203 \mathrm{~A} \rightarrow \mathrm{C}$ & $\mathrm{L} 401 \mathrm{~F}$ & ND & - \\
\hline
\end{tabular}

+ , mutation seen in direct sequencing of cDNA; ND, not done. 

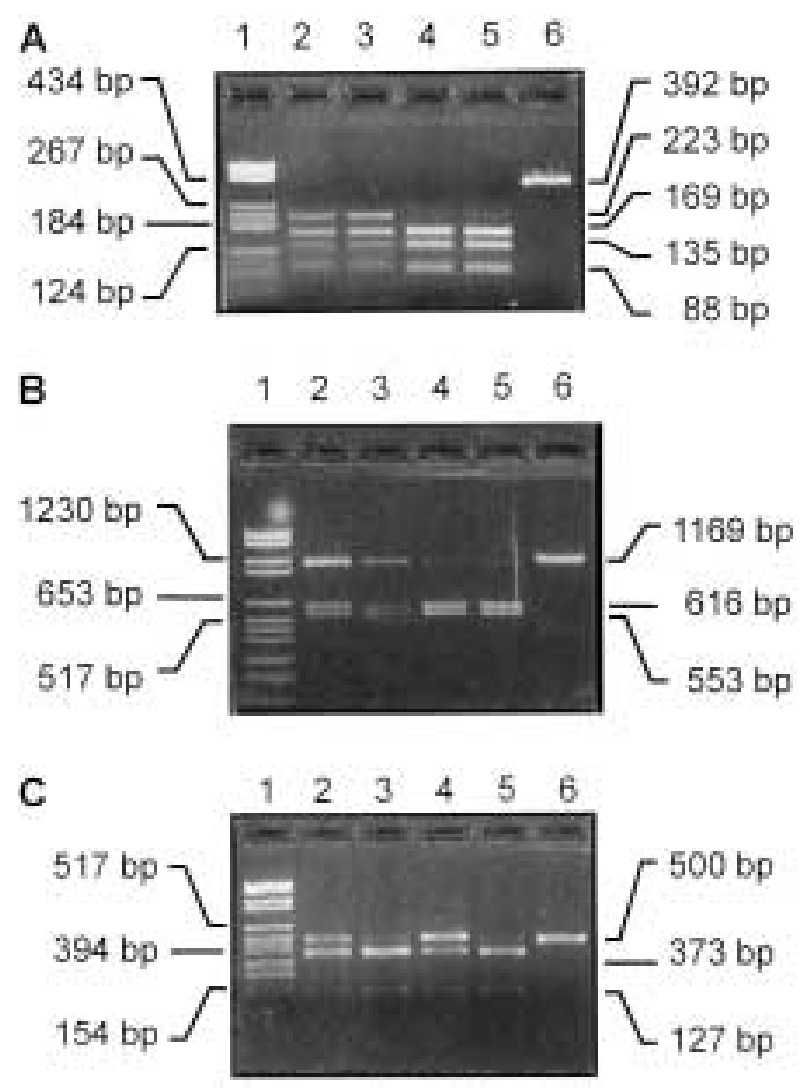

Fig. 3. Restriction site analysis of three mutations. (A) IVS2-2 a $\rightarrow$ c. After amplification a 392-bp fragment of genomic DNA is digested with BstNI. Lane 1 DNA molecular weight marker V (Boehringer Mannheim, Germany). The mutation abolishes a restriction site and an undigested 223-bp fragment can be demonstrated as an extra band in lanes 2 and 3; lanes 4 and 5 are healthy controls and lane 6 is an undigested sample. (B) $338 \mathrm{G} \rightarrow$ C. After amplification a 1260-bp fragment of genomic DNA is digested with Bsu36I. Lane 1 DNA molecular weight marker VI. The mutation abolishes a restriction site and an undigested 1169-bp fragment can be demonstrated as an extra band in lanes 2 and 3; lanes 4 and 5 are healthy controls and lane 6 is an undigested sample. (C) $470 \mathrm{~A} \rightarrow \mathrm{C}$. After amplification a 500-bp fragment of genomic DNA is digested using Bsu36I enzyme. Lane 1 DNA molecular weight marker IV. The mutation abolishes a restriction site and an undigested 500-bp fragment can be demonstrated as an extra band in lanes 2 and 4; lanes 3 and 5 are healthy controls and lane 6 is an undigested sample.

(L401F). The effect of this apparently mild amino acid change on the function of the enzyme is difficult to predict because the PPOX polypeptide has not been crystallized so far and a three-dimensional X-ray structure is not available. Homology comparisons made using ClustalX 1.8 with standard parameters showed that this leucine residue is conserved in human, mouse, and yeast but not in bacteria. The mutation segregated within the family and was not detected in any of 80 alleles of unrelated healthy controls excluding a common polymorphism. In addition, no other mutation was detected by direct sequencing in the proband's PPOX gene.
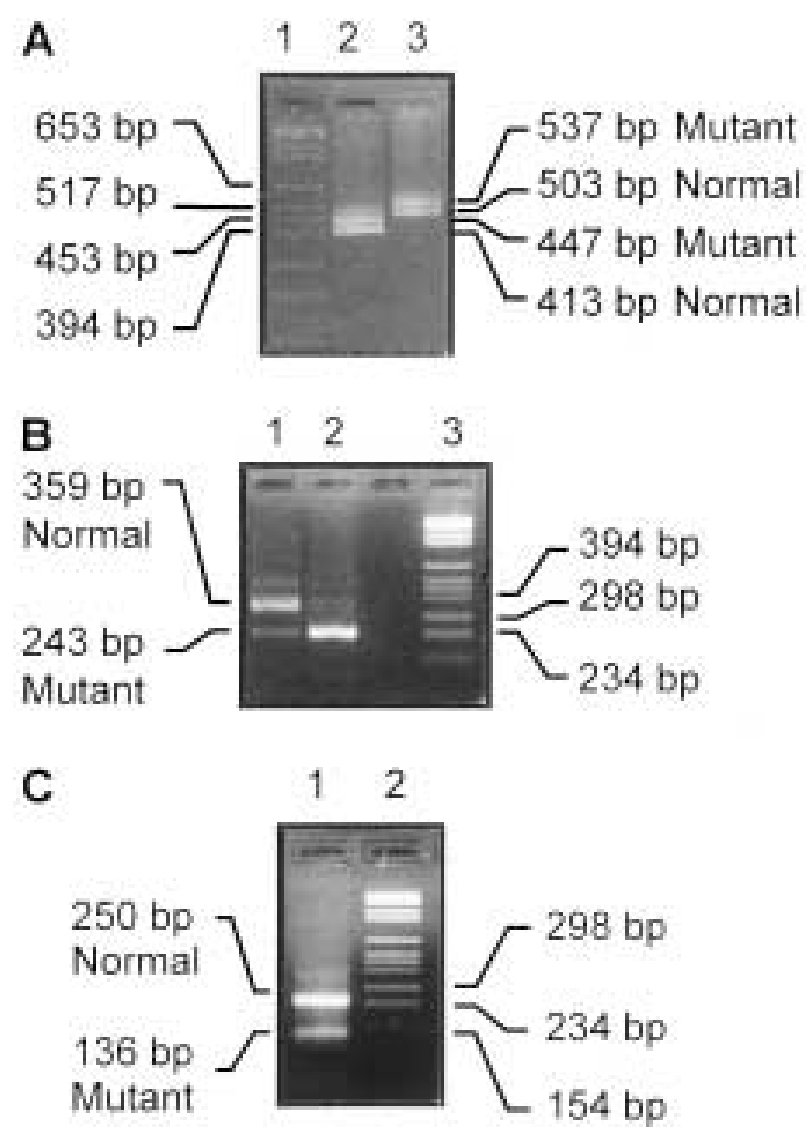

Fig. 4. Electrophoretic analysis of RT-PCR reveals a splicing defect in three cases. (A) IVS2-2 a $\rightarrow$ c; retention of a 34-bp fragment of the 3'-end of intron 2. Lane 1 DNA molecular weight marker VI (Boehringer Mannheim, Germany). Lane 2 A $413 \mathrm{bp}$ normal RT-PCR fragment including exons 2 to 5 and a 447 bp mutant fragment. Lane 3 A 503 bp normal RT-PCR fragment including exons 1 to 5 and a 537 bp mutant fragment. (B) $338 \mathrm{G} \rightarrow \mathrm{C}$; deletion of exon 4. Lane 1 A $359 \mathrm{bp}$ normal RT-PCR fragment including exons 3 to 5 and a 243 bp mutant fragment. Lane 2. The RT-PCR was reamplified after $B s a \mathrm{I}$ digestion abolishing the normal transcript. Lane 3 DNA molecular weight marker VI. (C) $470 \mathrm{~A} \rightarrow \mathrm{C}$; deletion of exon 5 and a $19 \mathrm{bp}$ retention of the 3 '-end of intron 5 result in a total deletion of $114 \mathrm{bp}$ in the mutant transcript. Lane 1 A $250 \mathrm{bp}$ normal RT-PCR fragment including exons 4 to 6 and a 136 bp mutant fragment. Lane 2 DNA molecular weight marker VI.

A missense mutation $454 \mathrm{C} \rightarrow \mathrm{T}$ mutation was identified from a total of 27 Finnish VP patients or their relatives belonging to 11 families, which were not previously known to be related according to pedigree analysis. In RT-PCR, the mutation could be identified in the cDNA. The mutation is predicted to result in an arginine to cysteine substitution (R152C).

\section{Expression of the PPOX Mutations}

To further characterize the PPOX mutations, the pUC18-prokaryotic expression vector for each of the mutant transcripts was constructed and expressed in 


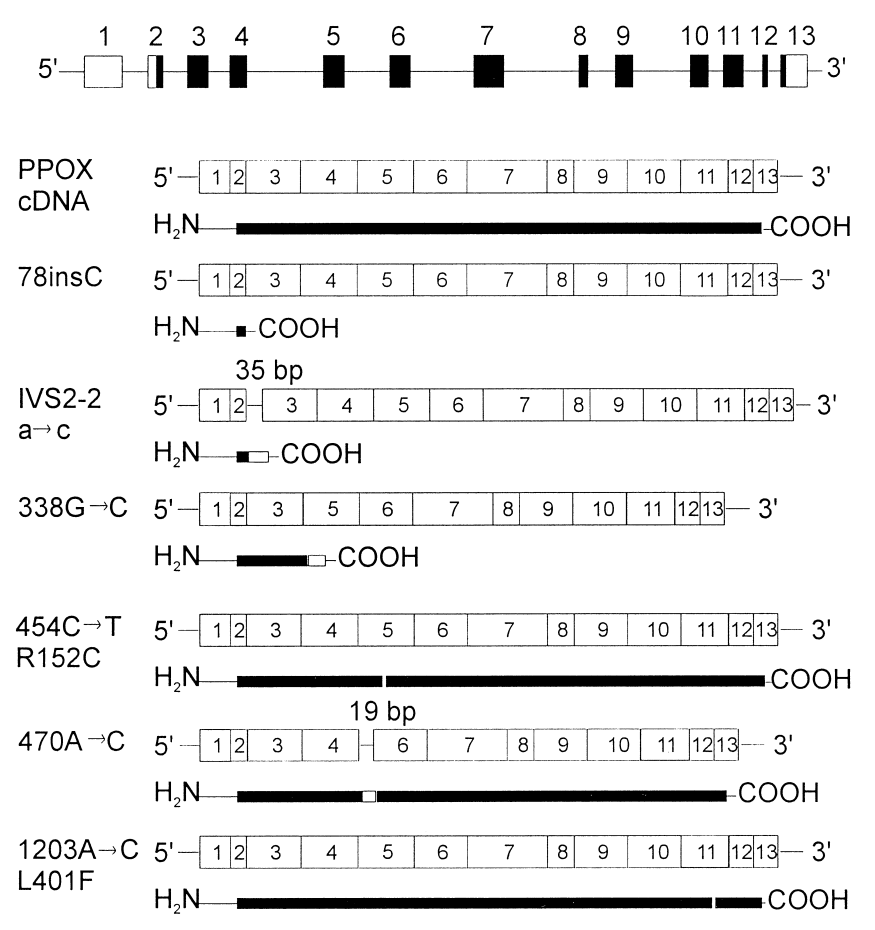

Fig. 5. Schematic representation of the consequences of mutations affecting splicing and protein translation. Above exon/intron structure of human PPOX gene; solid and open boxes represent protein-coding and untranslated regions. Below the cDNA and protein translation are shown for each mutation; solid bars represent normally translated amino acids and open bars represent nonsense amino acids.
E. coli and enzymatic activities were determined. Furthermore, a pCMV5-vector for each allele was constructed for transient expression in COS-1 cells. The cells were transfected either with the PPOX mutants, the wild-type PPOX or the vector alone.

Table 2 summarizes the PPOX activities of the normal transcripts and mutants expressed in $E$. coli and in COS-1 cells. In E. coli, at least five independent enzyme activity measurements and in COS-1 cells at least five independent transfections were performed. The normal alleles were found to have high levels of PPOX activity in both expression systems, $46.8 \pm 3.9 \mathrm{nmol} / \mathrm{g}$ prot in E. coli (mean \pm SEM) and $9.5 \pm 1.0 \mathrm{nmol} / \mathrm{g}$ prot in COS -1 cells. The 8.2-fold increase to the background activity in E. coli $(5.7 \pm 1.0 \mathrm{nmol} / \mathrm{g}$ prot$)$ and the 2.7 -fold increase in COS-1 cells $(3.5 \pm 0.5 \mathrm{nmol} / \mathrm{g}$ prot) validates the use of both expression systems. Both in E. coli and COS-1 cells the enzyme activities of all mutated alleles 78insC, IVS2-2 $\mathrm{a} \rightarrow \mathrm{C}, 338 \mathrm{G} \rightarrow \mathrm{C}, 454 \mathrm{C} \rightarrow \mathrm{T}$, and $470 \mathrm{~A} \rightarrow \mathrm{C}$ were decreased close to the background level (0-5\% of the wild-type activity), confirming the causality of the mutations and the biochemical defects in the disease.

\section{Discussion}

In this communication, six mutations, including three splicing defects, an insertion, and two amino acid substitutions, were identified among Finnish VP families. Five of the mutations identified in this study are novel, family-specific, mutations and found so far only in Finland. To date a total of seven mutations have been identified in the

Table 2. Expression of mutated protoporphyrinogen oxidase in E. coli and COS cells

\begin{tabular}{|c|c|c|c|c|}
\hline Cell & cDNA & Plasmid & $\begin{array}{c}\text { Total Activity } \\
\text { nmol/g prot } \\
\left(\text { mean } \pm S^{1} M^{1}\right)\end{array}$ & $\begin{array}{l}\text { PPOX } \\
\text { Activity } \\
\quad(\%)\end{array}$ \\
\hline \multirow[t]{7}{*}{ E. coli } & - & pUC18 & $5.7 \pm 1.0$ & 0 \\
\hline & Human PPOX & pUCl8 & $46.8 \pm 3.9$ & 100 \\
\hline & 78insC & pUCl8 & $4.6 \pm 1.4$ & 0 \\
\hline & IVS2-2 $a \rightarrow c$ & pUC18 & $5.5 \pm 1.3$ & 0 \\
\hline & $338 \mathrm{G} \rightarrow \mathrm{C}$ & pUC18 & $8.0 \pm 1.8$ & 5 \\
\hline & $454 \mathrm{C} \rightarrow \mathrm{T}$ & pUC18 & $7.9 \pm 1.2$ & 5 \\
\hline & $470 \mathrm{~A} \rightarrow \mathrm{C}$ & pUC18 & $6.3 \pm 1.3$ & 1 \\
\hline \multirow[t]{7}{*}{ Cos- 1} & - & pCMV5 & $3.5 \pm 0.5$ & 0 \\
\hline & Human PPOX & pCMV5 & $9.5 \pm 1.0$ & 100 \\
\hline & 78insC & pCMV5 & $1.7 \pm 0.8$ & 0 \\
\hline & IVS2-2 $\mathrm{a} \rightarrow \mathrm{c}$ & pCMV5 & $1.7 \pm 0.6$ & 0 \\
\hline & $338 \mathrm{G} \rightarrow \mathrm{C}$ & pCMV5 & $3.1 \pm 0.8$ & 0 \\
\hline & $454 \mathrm{C} \rightarrow \mathrm{T}$ & pCMV5 & $3.9 \pm 0.6$ & 5 \\
\hline & $470 \mathrm{~A} \rightarrow \mathrm{C}$ & pCMV5 & $3.0 \pm 1.5$ & 0 \\
\hline
\end{tabular}

\footnotetext{
${ }^{1}$ At least five independent transfections and/or enzyme activity measurements.
} 
Finnish population of 5 million covering all the 19 VP families known at present (4) and demonstrating the genetic heterogeneity of the disease also in Finland.

So far, 81 mutations have been reported in the PPOX gene worldwide and no mutational hot spots have been identified (8-19). Twenty-eight (35\%) of the mutations are small insertions or deletions that introduce a frameshift and a premature stop codon. Thirty-six $(44 \%)$ are missense mutations, 9 (11\%) change invariant nucleotides at splice sites, and 8 $(10 \%)$ produce stop codons $(8-19)$. The proportion of splice defects is comparable to a previous study, where 101 of 659 point mutations $(15 \%)$ occurred in splice junctions (30).

In our study of Finnish VP families, three of the six mutations were splicing defects. Two of the mutations are located at the $5^{\prime}$ donor splice site. Interestingly, in the case of mutation $338 \mathrm{G} \rightarrow \mathrm{C}(-1 \mathrm{G} \rightarrow \mathrm{C})$ exon skipping was preferred, although a potential cryptic splice site (ACAG/GTTC), which resembled the authentic splice site (TCAG/GTAA), existed $48 \mathrm{bp}$ upstream of the authentic splice site in exon 4 . This may support the "exon-definition hypothesis" derived from experimental analyses stating that each exon sequence in the pre-mRNA is defined and then the introns between the exons are recognized by splicing machinery (31). The model also implies that intron retention is permitted only when the intron is small enough to satisfy the exon length limitation. In this case the total length of exon 4 , intron 4 , and exon 5 was $756 \mathrm{bp}$, which possibly violates the length limitation and thus prevents intron 4 retention. On the contrary, multiple aberrant splicing patterns with simultaneous exon skipping and cryptic splice site activation, which was caused by the mutation $470 \mathrm{~A} \rightarrow \mathrm{C}$, appears to be an infrequent phenomenon, as it was not documented in the database consisting of 209 point mutations leading to aberrant splicing (32).

In the case of the mutation IVS2-2 $a \rightarrow c$, the $-2 a \rightarrow c$ substitution at the $3^{\prime}$ acceptor splice site of intron 2 causes a cryptic splice site activation $19 \mathrm{bp}$ upstream of the authentic splice site. Cryptic splice site activation is a relatively common phenomenon occurring in $30 \%$ of splice site mutations and most of the cryptic splice sites activated are located relatively near, usually within 100 nucleotides, of the authentic splice site (32). In the activation of $3^{\prime}$ cryptic splice sites, the cryptic sites downstream from the authentic sites are selected more frequently (32). In this case, however, the cryptic site was located upstream from the authentic site indicating that the splice site selection is not a simple one-way scanning process.

In RT-PCR, the mutation could be identified in cDNA in five cases and the relative amount of expressed mutant allele was estimated by comparing the bands corresponding to the mutant and wildtype alleles in the agarose gel. In the case of muta- tion $338 \mathrm{G} \rightarrow \mathrm{C}$, the RT-PCR revealed a dramatic decrease of the steady-state level of the mutant transcript in the patient's lymphocytes compared to that of the normal allele. Several nonsense or frameshift mutations have been shown to be associated with dramatic reductions in the steady-state level of cytoplasmic mRNA (33). However, no reduction in the mRNA level could be demonstrated by mutations 78insC, $470 \mathrm{~A} \rightarrow \mathrm{C}, 454 \mathrm{C} \rightarrow \mathrm{T}$, and IVS2 $-2 \mathrm{a} \rightarrow \mathrm{c}$. This is surprising, because the mutations 78insC and IVS2-2 $\mathrm{a} \rightarrow \mathrm{c}$ produce a termination codon near the $5^{\prime}$ end of the gene and normally, the closer a termination codon is to the $5^{\prime}$ end of the gene, the higher the level of mRNA transcripts is likely to be (33).

Five of the mutations, 78insC, IVS2-2 a $\rightarrow c$, $338 \mathrm{G} \rightarrow \mathrm{C}, 454 \mathrm{C} \rightarrow \mathrm{T}$, and $470 \mathrm{~A} \rightarrow \mathrm{C}$, were expressed in both E. coli and mammalian COS-1 cells. All mutated constructs resulted in decreased PPOX activity, thus confirming the causality of the mutations and the disease. Previously, three reports have been published in which the consequences of mutations responsible for VP have been analyzed in a prokaryotic expression system $(8,16,34)$. The mutation R59W resulted in a loss of enzyme activity (8), whereas in mutations D349A, G358R, A433P and A219KANA $9.5-25 \%$ of the wild type activity was preserved $(16,34)$.

The mutations 78insC, IVS2-2 $\mathrm{a} \rightarrow \mathrm{c}$, and $338 \mathrm{G} \rightarrow \mathrm{C}$ were predicted to result in a truncated polypeptide including less than 103 of the 477 amino acids $(22 \%)$ of the normal polypeptide (Fig. 5$)$. The loss of enzymatic function of these truncated polypeptides was predictable and could be confirmed by expression studies in prokaryotic and eukaryotic cells, where $0-5 \%$ of the wild-type enzyme activity was observed indicating no significant difference to the background activity. The mutation $470 \mathrm{~A} \rightarrow \mathrm{C}$ was predicted to result in a polypeptide, where 45 amino acids encoded by exon 5 are replaced by seven nonsense amino acids encoded by the inserted fragment of intron 5 . Less than $1 \%$ enzyme activity was observed in both E. coli and COS-1 cells, indicating that the domain coded by exon 5 is essential for the enzyme function. In the case of the mutation $454 \mathrm{C} \rightarrow \mathrm{T}$, substitution of basic arginine residue by neutral, sulphur-containing amino acid cysteine (R152C) resulted in a dramatic decrease of enzyme activity (5\% of the wild-type activity) in both E. coli and COS-1 cells. This confirms the causality of the mutation and the disease. This arginine residue is evolutionary conserved in humans, mice, bacteria, yeast, and plants indicating the importance of this residue for PPOX function (17).

This is the first report of PPOX expression in mammalian cells. Expression studies performed in bacterial or mammalian cells may give controversial results due to the different localization and transport mechanisms of the expressed polypeptide in different cell systems. In many prokaryotes studied, 
PPOX is bound to cytoplasmic membrane and is coupled to the cell's respiratory chain (2). In contrast, the Bacillus oxidase overexpressed in E. coli is soluble and includes no membrane spanning structure (35). In our study, however, no major discrepancy between prokaryotic and eukaryotic expression systems could be observed.

In conclusion, DNA diagnostic testing is now provided for members of all known Finnish VP families. The most sensitive biochemical tests for diagnosis of VP, namely fecal and plasma porphyrin measurements, detect less than $80 \%$ of individuals with PPOX mutations in VP families. A mutation analysis is a convenient test and the only reliable way to identify the asymptomatic family members and to provide precise genetic counseling for individuals at risk.

\section{Acknowledgments}

We thank medical students Ms. Jamelah Tucker and Ms. Katri Kuusisto for their excellent assistance in sequencing. This study was supported by grants from the Magnus Ehrnrooth Foundation, the Finnish Cultural Foundation, the Research Funds and the Clinical Research Institute of the Helsinki University Central Hospital, the Biomedicum Helsinki Foundation, and the University of Helsinki.

\section{References}

1. Kappas A, Sassa S, Galbraith RA, Nordmann Y. (1995) The porphyrias. In: Scriver CR, Beaudet A, Sly WS, Valle D, eds. The metabolic and molecular bases of inherited diseases, McGrawHill, New York, pp. 2116-2127.

2. Dailey HA. (1990) Conversion of coproporphyrinogen to proto hem in higher eukaryotes and bacteria: terminal three enzymes. In: Dailey HA, ed. Biosynthesis of heme and chlorophylls, McGraw-Hill, New York, pp. 123-161.

3. Deybach JC, de Verneuil H, Nordmann Y. (1981) The inherited enzymatic defect in porphyria variegata. Hum. Genet. 58: 425-428.

4. Mustajoki P. (1980) Variegate porphyria. Twelve years' experience in Finland. Q. J. Med. 49: 191-203.

5. Nishimura K, Taketani S, Inokuchi H. (1995) Cloning of a human cDNA for protoporphyrinogen oxidase by complementation in vivo of a hemG mutant of Escherichia coli. J. Biol. Chem. 270: 8076-8080.

6. Roberts AG, Whatley SD, Daniels J, et al. (1995) Partial characterization and assignment of the gene for protoporphyrinogen oxidase and variegate porphyria to human chromosome 1q23. Hum. Mol. Genet. 4: 2387-2390.

7. Puy H, Robreau AM, Rosipal R, Nordmann Y, Deybach JC. (1996) Protoporphyrinogen oxidase: complete genomic sequence and polymorphisms in the human gene. Biochem. Biophys. Res. Comm. 226: 226-230.

8. Meissner PN, Dailey TA, Hift RJ, et al. (1996) A R59W mutation in human protoporphyrinogen oxidase results in decreased enzyme activity and is prevalent in South Africans with variegate porphyria [see comments]. Nat. Genet. 13: 95-97.

9. Warnich L, Kotze MJ, Groenewald IM, et al. (1996) Identification of three mutations and associated haplotypes in the protoporphyrinogen oxidase gene in South African families with variegate porphyria. Hum. Mol. Genet. 5: 981-984.
10. Deybach JC, Puy H, Robreau AM, et al. (1996) Mutations in the protoporphyrinogen oxidase gene in patients with variegate porphyria. Hum. Mol. Genet. 5: 407-410.

11. Lam H, Dragan L, Tsou HC, et al. (1997) Molecular basis of variegate porphyria: a de novo insertion mutation in the protoporphyrinogen oxidase gene. Hum. Genet. 99: 126129.

12. Frank J, Christiano A. (1997) Genetic research strategies: a review of the acute porphyrias. Retinoids 13: 88-92.

13. Frank J, Jugert FK, Kalka K, Goerz G, Merk HF, Christiano AM. (1998) Variegate porphyria: identification of a nonsense mutation in the protoporphyrinogen oxidase gene. J. Invest. Dermatol. 110: 449-451.

14. Frank J, McGrath J, Lam H, Graham RM, Hawk JL, Christiano AM. (1998) Homozygous variegate porphyria: identification of mutations on both alleles of the protoporphyrinogen oxidase gene in a severely affected proband. J. Invest. Dermatol. 110: 452-455.

15. Frank J, Lam H, Zaider E, Poh-Fitzpatrick M, Christiano AM. (1998) Molecular basis of variegate porphyria: a missense mutation in the protoporphyrinogen oxidase gene. J. Med. Genet. 35: 244-247.

16. Roberts AG, Puy H, Dailey TA, et al. (1998) Molecular characterization of homozygous variegate porphyria. Hum. Mol. Genet. 7: 1921-1925.

17. Frank J, Poh-Fitzpatrick MB, King LE Jr, Christiano AM. (1998) The genetic basis of "Scarsdale Gourmet Diet" variegate porphyria: a missense mutation in the protoporphyrinogen oxidase gene. Arch. Dermatol. Res. 290: 441-445.

18. Corrigall AV, Hift RJ, Hancock V, et al. (1998) Identification and characterisation of a deletion (537delAT) in the protoporphyrinogen oxidase gene in a South African variegate porphyria family. Hum. Mutat. 12: 403-407.

19. Whatley SD, Puy H, Morgan RR, (1999) Variegate porphyria in Western Europe. Identification of PPOX gene mutations in 104 families, extent of allelic heterogenity, and absence of correlation between phenotype and type of mutation. Am. J. Hum. Genet. 65: 984-994.

20. Kauppinen R, Mustajoki P. (1992) Prognosis of acute porphyria: occurrence of acute attacks, precipitating factors, and associated diseases. Medicine 71: 1-13.

21. Timonen K, Niemi KM, Mustajoki P, Tenhunen R. (1990) Skin changes in variegate porphyria. Clinical, histopathological, and ultrastructural study. Arch. Dermatol. Res. 282: 108-114.

22. Li F, Lim CK, Peters TJ. (1986) Analysis of urine and faecal porphyrins by HPLC coupled to an advanced automated sample processor. Biomed. Chromatogr. 1: 93-94.

23. Poh-Fitzpatrick MB. (1980) A plasma porphyrin fluorescence marker for variegate porphyria. Arch. Dermatol. 116: 543-547.

24. Higuchi $R$ (1989) Simple and rapid preparation of samples for PCR. In: Ehrlich HA, ed. PCR technology. Principles and applications for DNA amplification. New York, Stockton Press, pp. 31-38.

25. Chirgwin JM, Przybyla AE, MacDonald RJ, Rutter WJ. (1979) Isolation of biologically active ribonucleic acid from sources enriched in ribonuclease. Biochemistry 18: 5294-5299.

26. Sambrook J, Fritsch EF, Maniatis T. (1989) Molecular cloning: a laboratory manual. Cold Spring Harbor, NY, Cold Spring Harbor Laboratory Press, 9.16-9.19.

27. Mullis KB, Faloona F. (1987) Specific synthesis of DNA in vitro via a polymerase-catalyzed chain reaction. Methods Enzymol. 155: 335-350.

28. Sanger F, Nicklen S, Coulson AR. (1977) DNA sequencing with chain-terminating inhibitors. Proc. Natl. Acad. Sci. U.S.A. 74: 5463-5467.

29. Andersson S, Davis DL, Dahlback H, Jornvall H, Russell DW. (1989) Cloning, structure, and expression of the mitochondrial cytochrome P-450 sterol 26-hydroxylase, a bile acid biosynthetic enzyme. J. Biol. Chem. 264: 8222-8229.

30. Krawczak M, Reiss J, Cooper DN. (1992) The mutational spectrum of single base-pair substitutions in mRNA splice 
junctions of human genes: causes and consequences. Hum. Genet. 90: 41-54.

31. Niwa M, MacDonald CC, Berget SM. (1992) Are vertebrate exons scanned during splice-site selection? Nature 360: 277-280.

32. Nakai K, Sakamoto H. (1994) Construction of a novel database containing aberrant splicing mutations of mammalian genes. Gene 141: 171-177.
33. Cooper DN. (1993) Human gene mutations affecting RNA processing and translation. Ann. Med. 25: 11-17.

34. Dailey HA, Dailey TA. (1997) Characteristics of human protoporphyrinogen oxidase in controls and variegate porphyrias. Cell. Molec. Biol. 43: 67-73.

35. Dailey TA, Meissner P, Dailey HA. (1994) Expression of a cloned protoporphyrinogen oxidase. J. Biol. Chem. 269: 813-815. 